\title{
O HOMEM DO POVO: OSWALD DE ANDRADE E O JORNALISMO ENGAJADO
}

\author{
Valdeci da Silva Cunha \\ Mestrando em História - História e Culturas Políticas / UFMG
}

\begin{abstract}
RESUMO
Este artigo analisa o jornal O Homem do Povo, criado e publicado por Oswald de Andrade, em 1931, a partir do conceito de representação. Ocupa-se em entender quais foram as utilizações da ideia de povo, assim como a sua autorrepresentação como intelectual engajado em questões políticas.
\end{abstract}

\section{PALAVRAS-CHAVE}

Oswald de Andrade, história dos intelectuais, representações políticas

No ano de 1931, Oswald de Andrade deu início à criação e à publicação do jornal político intitulado O Homem do Povo. ${ }^{1}$ Marcado por uma efêmera existência foram publicados oito números, entre os meses de março e abril. Criado poucos anos após a extinção da Revista de Antropofagia (1928-29), esse impresso apresentou-se, diferentemente desta, como a manifestação das primeiras aproximações de Oswald com o ativismo e o pensamento político marxistas, questão essa que aparecerá em sua produção ao longo dos anos de 193040. Por conseguinte, é nesse mesmo momento de publicação do impresso que se dará a filiação do mesmo ao Partido Comunista Brasileiro, que se estenderá até o ano de 1945.

Este trabalho tem como intenção a leitura do jornal $O$ Homem do Povo a partir do conceito de representação, tanto no que diz respeito à utilização da ideia de "povo”, como, a partir dessa equação, também perceber como o próprio Oswald de Andrade construiu, permanentemente, sua própria representação de intelectual. Entendido ora por sua constante irreverência e ironia, ora ignorado por parte dos contemporâneos como intelectual herdeiro de

\footnotetext{
${ }^{1}$ Esse não foi o primeiro, nem o único empreendimento oswaldiano com o jornalismo. Seu interesse pelo mesmo nasce já na sua juventude e o acompanhará por toda a sua trajetória. CHALMERS. 3 linhas e 4 verdades: o jornalismo de Oswald de Andrade.
} 
uma lógica boêmia alocada nos finais do século 19, pretendemos apreender esse universo complexo e hermético de seus posicionamentos. Também foi de nosso interesse pincelar a análise com outros textos da produção oswaldiana, ao tentarmos estabelecer possíveis diálogos.

Em artigo intitulado "Representação política: o reconhecimento de um conceito na historiografia brasileira”, as professoras Eliana Dutra e Maria Capelato chegam a afirmar que

em qualquer balanço historiográfico no Brasil de hoje que tome por base o quadro de pesquisa dos historiadores do político, é forçoso reconhecer como o recurso ao conceito de "representação", ou a seu contratermo "imaginário", é cada vez mais freqüente, e privilegiado, no intuito de estabelecer a inteligibilidade histórica das sociedades políticas e dos fenômenos afeitos ao campo do político. ${ }^{2}$

Interessante perceber que, ao fazer um balanço sobre trabalhos acadêmicos produzidos a partir da década de 1990 no Brasil, que utilizaram o conceito plural de representação, o artigo também leva em consideração a importante reestruturação da noção de política. Ao destacar o lugar do político nesses estudos, em detrimento da noção ampla de política, evidencia a importância da mudança dessa concepção no que diz respeito à incorporação do conceito de imaginação e imaginário políticos. Ainda para as autoras, "a relação simbólica, entre o signo e o que ele dá a conhecer, é, portanto, uma relação de representação, em que o signo toma o lugar da coisa representada, que só pode se efetuar com o recurso do imaginário". 3

Para Carlo Ginzburg,

a "representação" faz às vezes da realidade representada e, portanto, evoca a ausência; por outro, torna visível a realidade representada e, portanto, sugere a presença. Mas a contraposição poderia ser facilmente invertida: no primeiro caso, a representação é presente, ainda que como sucedâneo; no segundo, ela acaba remetendo, por contraste, à realidade ausente que pretende representar. ${ }^{4}$

Outro ponto que nos interessa é a discussão em torno das diferenciações e aproximações entre as noções da política e do político. René Rémond, no texto intitulado "Do político", destaca que "se o político é uma construção abstrata, assim como o econômico e o

\footnotetext{
${ }^{2}$ DUTRA; CAPELATO. Representação política: de um conceito na historiografia brasileira, p. 227.

${ }^{3}$ DUTRA; CAPELATO. Representação política: de um conceito na historiografia brasileira, p. 228.

${ }^{4}$ GINZBURG. Representação: a palavra, a idéia, a coisa, p. 85.
} 
social, é também a coisa mais concreta com que todos se deparam na vida, algo que interfere na sua atividade profissional ou se imiscui na vida privada”. Por conseguinte,

o político não tem fronteiras naturais. Ora se dilata até incluir toda e qualquer realidade e absorver a esfera do privado: este é um traço das sociedades autoritárias. Ora ele se retrai ao extremo. Essas variações obedecem a necessidades externas; refletem também as flutuações do espírito público. ${ }^{5}$

Rodrigo Patto Sá Motta, no texto "Batalhas em torno do mito: Luiz Carlos Prestes”, destaca que, "sem dúvida, Luiz Carlos Prestes foi a figura mais importante da história do comunismo no Brasil”, ${ }^{6}$ e chama a atenção para a importância de sua trajetória, tanto no que diz respeito à sua atuação na arena política, quanto às apropriações/representações colocadas em disputa pelo PCB e pelos anticomunistas, mesmo não desconsiderando a importância de nomes como Astrojildo Pereira (fundador do PCB), Otávio Brandão ou Giocondo Dias. Assim, para Motta,

o destaque maior que atribuímos a Prestes deve-se ao fato de ter sido ele o dirigente com mais tempo de permanência à testa do Partido Comunista cerca de quarenta anos -, e o que possuiu mais forte dose de carisma, uma popularidade que, em determinados contextos, era superior à do próprio partido. $^{7}$

Nesse trabalho, Motta matiza os vários momentos em que a imagem de Luiz Carlos Prestes foi utilizada dentro e fora dos debates em torno da história do movimento comunista brasileiro, assim como as várias mitologias sustentadas tanto por militantes do PCB, como pelos anticomunistas.

Helena Bomeny, em seu texto “Infidelidades eletivas: intelectuais e o poder”, ao tomar de empréstimo as categorias usadas por Guerreiro Ramos, ilustra a complexidade das relações dos intelectuais brasileiros com a política dos anos 1930. Segundo Bomeny, entre as principais figuras consideradas representativas da vida intelectual dessa mesma década, classificadas como possuidoras do "pragmatismo cêntrico", marcam presença nomes como Francisco Campos, Gustavo Capanema e Lindolfo Collor, mas cada um à sua maneira, tanto como ideólogos, quanto como políticos. Para a autora, nomes como Gilberto Amado, Caio

\footnotetext{
${ }^{5}$ RÉMOND. Do político, p. 442.

${ }^{6}$ MOTTA. Batalhas em torno do mito: Luiz Carlos Prestes, p. 91.

${ }^{7}$ MOTTA. Batalhas em torno do mito: Luiz Carlos Prestes, p. 91.
} 
Prado Junior e Nestor Duarte seriam entendidos como intelectuais “independentes”. Uma terceira classificação estaria ancorada na categoria de intelectuais “confrontivos”. Nesse sentido, seriam incluídos nomes como o de Luiz Carlos Prestes, Otávio Mangabeira, Aparício Toreli (o barão de Itararé) e outros.

Interessante perceber, ao seguirmos as análises de Bomeny, mesmo que a referência a “outros” não se configure como uma categoria interpretativa, a sugestão da dificuldade de enquadramento de alguns intelectuais - e talvez por esse motivo o nome de Oswald de Andrade não constar em sua lista - em modelos reducionistas. Talvez, para não perdemos essa indicação, poderíamos entendê-lo como um intelectual independente e confrontivo. Entretanto, é necessário tentar expandir um pouco mais o espectro dessa análise.

Outra questão interessante é a colocada em torno da noção de mito/mitologia, trabalhada por Motta. Ela nos sugere a possibilidade analítica de a extrapolarmos no sentido da figura do herói, ou do heroísmo, na modernidade. Nesse sentido, é pertinente pensarmos nos limites que a morte traz em relação às concepções de invulnerabilidade, finitude ou mesmo nos deslocamentos no olhar daqueles que se prestam a uma revisitação de sua própria conduta/trajetória em autobiografias. ${ }^{8}$

A questão em torno do mito nos parece bem desenvolvida na dissertação Um ciclone na paulicéia: Oswald de Andrade e os limites da vida intelectual em São Paulo (1900-50). Nesse trabalho, ao utilizar a noção de campo de Pierre Bourdieu, Rubens de Oliveira Martins traça os caminhos percorridos no Brasil para a construção do seu campo intelectual, partindo da constatação da existência de uma "intelectualidade boêmia”, herdeira de uma lógica de sociabilidade de meados do século 10, e as mudanças provocadas pelas novas configurações advindas da Proclamação da República. Nesse sentido, dois momentos da história do pensamento social brasileiro parecem ser cruciais para a sua análise: a criação da Academia Brasileira de Letras (1894) e a fundação da Universidade de São Paulo (1934). A primeira representada através da figura emblemática de Machado de Assis e suas polêmicas em relação aos intelectuais boêmios (com a figura emblemática manifestada em Emílio de Menezes); a segunda, ao conferir uma nova dimensão em torno da pesquisa séria, acadêmica e sistêmica, representada pelas figuras de Mário de Andrade e Sérgio Milliet. Estes, tidos como

\footnotetext{
${ }^{8}$ Esses elementos, que teriam a função de conferir ou convergir a noção de identidades imaginárias, teriam sua sobrevivência tornada problemática com a modernidade, principalmente ao pensarmos o herói convergido em espetáculo. MATOS. Construção e desaparecimento do herói: uma questão de identidade nacional.
} 
representantes da postura do intelectual "sério e comprometido", criando, como contraponto, a figura do intelectual "irreverente e irônico" e, nesse sentido, "nada acadêmico”, ilustrado na figura de Oswald de Andrade. Ainda segundo o autor, essa divisão teria conferido às memórias sobre Oswald ora o lugar de mitológico, ligado ao intelectual antiacadêmico, ora o relegado ao esquecimento ou a marginalidade. ${ }^{9}$

Curiosa constatação que, mesmo que suscite uma série de críticas e polêmicas como, por exemplo, as que cercam as duas tentativas de enquadramento de Oswald às fileiras da intelectualidade acadêmica tanto em 1945, com a tese A Arcádia e a Inconfidência, e em 1950, com a tese A crise da filosofia messiânica, nos remete às considerações feitas por Edward Said, em que o cerne da questão se refere às representações do intelectual na modernidade. Para o autor,

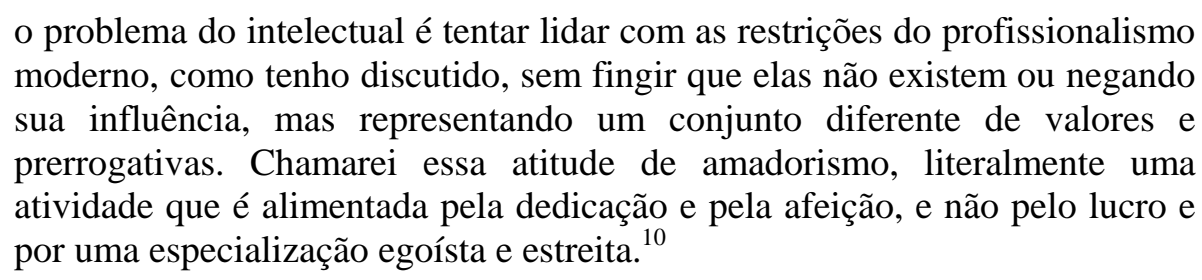

Outro exemplo que nos ajuda a pensar, em que pesem as distâncias temporais e o risco do anacronismo, é o lugar ocupado por Jean-Paul Sartre como intelectual total. ${ }^{11}$ Em seu livro intitulado Em defesa dos intelectuais, resultado de três conferências que tiveram lugar o Japão no pós-Segunda Guerra Mundial, Sartre dá algumas pistas valiosas para a configuração de condutas para a atuação dos intelectuais, frente às exigências de seu tempo. Ao evidenciar a importância do Caso Dreyfus, situado no final do século 19, considera que esse evento teve um papel importante no que toca a atuação dos intelectuais na cena pública. Segundo Sartre, intelectuais (da Ciência ou da Literatura, no caso, Émile Zola) entraram em assuntos que não entendiam. Nesse sentido, “o intelectual moderno [seria] um homem-contradição”. ${ }^{12}$ Uma imagem curiosa referida pelo mesmo nos auxilia a pensar as possíveis tentativas de delimitação dos lugares ocupados por cientistas e intelectuais: os primeiros, por exemplo,

\footnotetext{
${ }^{9}$ MARTINS. Um ciclone da paulicéia: Oswald de Andrade e os limites da vida intelectual em São Paulo (1900-50).

${ }^{10}$ SAID. Profissionais e amadores, p. 86.

${ }^{11}$ Termo cunhado por Pierre Bourdieu. BOURDIEU. As regras da arte.

${ }^{12}$ SARTRE. O que é o intelectual, p. 15.
} 
poderiam se dedicar à construção de uma bomba atômica; os segundos teriam o dever de se prestarem à contestação da construção dessa mesma bomba.

De certa forma, tanto a ideia de um posicionamento “amador”, quanto a do intelectual como um "homem-contradição" conferem um referencial interessante para as análises que se prestam a tentar apreender as complexidades da atuação de Oswald. Ao termos em vista suas posições, que poderíamos chamar, em grande medida, de marginal dentro das configurações do campo intelectual paulista, os embates que sustentou durante sua atuação e militância políticas não se enquadrariam em conceitos como o de intelectual orgânico (Gramsci) ou do intelectual específico (Foucault).

Ao fim e ao cabo, nos interessou no presente texto como ou de que maneira as representações políticas oswaldianas sobre as noções de povo foram construídas e/ou alvo de disputas. Como, ao utilizar-se de estratégias argumentativas, somadas a um possível imaginário social, em consonância com aquelas, Oswald tentou movimentar ou instigar ações práticas no que diz respeito à realidade sociopolítica de seu tempo? Como, por consequência, se propôs a criar um repertório comum de noções ou prescrições para a atuação deste mesmo povo nos debates políticos? Estaria presente em seus argumentos e/ou em suas práticas políticas um "horizonte de expectativa"13 de criação de uma moralidade que pudesse informar socialmente a construção de um novo homem, à luz de uma revolução social?

O presente texto é uma tentativa inicial de estudo de um momento específico da trajetória de Oswald de Andrade no cenário político dos anos 1930, que, em alguns momentos, esteve relegado ao esquecimento ou mesmo tido como pouco interessante para se pensar a história dos intelectuais e do pensamento social no Brasil e/ou a importância das tomadas de posição dos mesmos nos debates travados nesse mesmo período, assim como posterior a ele. ${ }^{14}$ Nesse sentido, entendemos que esse preliminar estudo se enquadra na

${ }^{13}$ KOSELLECK. Futuro passado: contribuição para a semântica dos tempos históricos.

${ }^{14}$ Estamos pensando em dois momentos específicos da história da crítica às obras de Oswald: o primeiro se deu com a criação da revista de cultura Clima, na década de 1940, em que a releitura dos textos de Oswald marcou uma espécie de revalorização dos seus escritos. Segundo Martins, "confirmando a existência de uma estratégia de omissão e da obra de Oswald (...) foi a revista Clima que retomou a discussão da sua obra, num momento [citando Antonio Candido] quando estava em moda considerá-lo um piadista de gênio (...). Naquela altura havia uma espécie de soberania intelectual exercida por Mário de Andrade em São Paulo (...) à volta dele juntava-se o grosso da vida literária e Oswald ficava meio à margem”. MARTINS. Um ciclone da paulicéia: Oswald de Andrade e os limites da vida intelectual em São Paulo (1900-50), p. 53-4. O segundo, com a montagem da peça O rei da vela, na década de 1960 pelo grupo de Teatro Oficina. Sabato 
perspectiva historiográfica conhecida como "nova história política”, 15 tanto no que tange às contribuições teórico-metodológicas dessa vertente, como em relação aos objetivos deste estudo.

Por tratarmos de um período marcado pela aproximação de Oswald de Andrade com o pensamento e a militância comunistas, também é de nosso interesse as discussões que tentam perceber a presença de uma cultura política comunista no Brasil. Nesse sentido, interessaramnos trabalhos que se ocuparam com o conceito de cultura política. ${ }^{16}$

Assim, a partir de uma efêmera publicação jornalística intitulada $O$ Homem do Povo, que marcou as primeiras manifestações de Oswald a partir do ideário comunista, achou-se relevante um mapeamento inicial a partir desse impresso. Tentamos perceber possíveis permanências e/ou rupturas tanto em suas tomadas de posição, como em sua escrita nos anos de sua militância política. Ao mesmo tempo, percebermos como, a partir desse momento, deuse início a uma incessante autoconstrução de sua imagem como intelectual militante, ${ }^{17}$ algo como uma reiterada "escrita de si mesmo”, no sentido da criação ou legitimação do seu papel e atuação como fala/figura autorizada no que tange à sua participação política. ${ }^{18}$

Magaldi, em prefácio à edição de 1990, comenta que "eu só [mei dei] conta, de fato, da virulência antecipadora de O rei da vela quando Procópio Ferreira, em 1967, por ocasião da montagem do Teatro Oficina de São Paulo, justificou não ter interpretado o texto, na década de 30: como poderia tê-lo feito, se naquele momento a Censura impedia que se pronunciasse no palco a palavra 'amante'? Por isso não coube a Oswald de Andrade a primazia da criação do teatro moderno, título ostentado por Nelson Rodrigues, ao estrear, em 1943, Vestido de noiva”. ANDRADE. O rei da vela, p. 7.

${ }^{15}$ RÉMOND. Do político.

${ }^{16}$ Segundo Motta, “a definição de cultura é extremamente polêmica. Mesmo entre os antropólogos, cuja contribuição nesta área é extremamente valorosa, não há consenso quanto ao estabelecimento do significado do conceito.” Para fins práticos, mesmo não sendo consensual, podemos pensar em cultura, como um "conjunto complexo constituído pela linguagem, comportamento, valores, crenças, representações e tradições partilhadas por determinado grupo humano e que lhe confere uma identidade”. MOTTA. O conceito de cultura política, p. 83-91. Ver também: RIOUX; SIRINELLI. Para uma história cultural, p. 394-363; DUTRA. História e culturas políticas: definições, usos, genealogias, p. 13-28.

${ }^{17}$ No ano de 1933, Oswald de Andrade publicou o prefácio definitivo de sua mais importante obra, Serafim Ponte Grande. Antes da edição final, o livro recebera um outro prefácio, de 1926. Nele é perceptível a ênfase na tentativa de "canonização" do Movimento Modernista como escola literária , assim como a tentativa de ratificação da Antropofagia - na medida em que apresentava o romance como um processo acabado de uma literatura "verdadeiramente" nacional. No prefácio de 33, Oswald assumia uma postura definitiva, negando seu passado burguês ao afirmar estar "possuído de uma única vontade. Ser, pelo menos, casaca de ferro na Revolução Proletária”. ANDRADE. Prefácio.

${ }^{18}$ Em 1945, Oswald de Andrade, aproveitando-se da visita do poeta chileno Pablo Neruda ao Brasil, 
No presente trabalho focaremos nossa análise em torno das representações construídas em torno das ideias de povo, ou melhor, quem seria esse homem do povo, questão central que perpassa todos os temas abordados pelo impresso. Acreditamos que a partir desse locus consigamos estabelecer algum contato com as aporias referidas logo acima. Entretanto, sem cairmos em simplismos, evitaremos tipificações binominais ao nos atermos aos perigos de serem estabelecidas contraposições do tipo comunismo $x$ autoritarismo, modernidade $x$ atraso etc., em uma tentativa de compreensão das complexas relações vividas entre as teorias e as práticas socioculturais.

Já na primeira edição do impresso em questão percebemos em letras garrafais o título O HOMEM DO POVO ocupando um quarto da página. Logo a seguir, informações que indicam que o mesmo seria dirigido pelo homem do povo - impresso em letras minúsculas -, e a referência de que se tratava de uma publicação que abordaria os problemas da cidade, do país e do mundo. Essas características, por conseguinte, acompanharam todas as edições seguintes. Em editorial assinado pelo próprio Oswald de Andrade, intitulado “Ordem e Progresso”, uma espécie de manifesto das razões de ser da publicação, destacamos a seguinte passagem:

Não temos generais, nem profetas. Somos a opinião livre, mas bem informada. Sabemos nos colocar no espaço-tempo. Sabemos que existe uma corrente separatista que prefere a ocupação estrangeira à evolução do Brasil no estouro do mundo pela guerra e pela revolução social. Sabemos que nas fronteiras do sul existe um grande chefe capaz de criar uma aventura de caráter romântico popular. Sabemos que o partido comunista, auxiliado pelos fatos, prepara as massas das oficinas e dos campos (...). Sabemos que há místicos estômagos vazios no nordeste, cavadores ao sul, indiferentes a oeste, canhões imperialistas no nosso mar. Sabemos que existe uma ala canhota no mundo e aqui. Nesta se encartam os que acreditam ser da

fez algumas ironias aos dirigentes do Partido Comunista do Brasil que "menosprezavam o trabalho dos escritores": "Neruda vem afirmar a São Paulo uma velha verdade - é possível ser comunista e ser culto. $\mathrm{O}$ intelectual faz apenas o seu dever oferecendo ao proletariado as suas riquezas culturais e a sua experiência vital e poética." Ainda para a autora, [Oswald] "lembrou a natureza da poesia ao longo dos séculos - 'instrumento de revolta, de oposição e de queixa'. Segundo ele, idéia semelhante à definição tradicional de comunismo.” Para Boaventura, entretanto, ao lançar mão de um comentário acusatório, a "fala de Oswald foi curta, cheia de afirmações equivocadas, ingenuamente utópicas e marcadas pela emoção". BOAVENTURA. O salão e a selva: uma biografia ilustrada de Oswald de Andrade, p. 218. 
esquerda, [mas] não passam de direitistas confusos. Entre uns e outros nos colocamos com uma imensa e clara simpatia pelas reivindicações da nossa gente explorada. Nosso programa é simples - basta entrarmos na nossa bandeira. Dar vida, força e sentido a um lema que até ontem parecia vazio e irônico - ORDEM E PROGRESSO. Milagre das idéias subversivas! Queremos a revolução social como etapa da harmonia planetária que nos promete a era da máquina. ${ }^{19}$

O trecho citado evidencia o caráter universalista presente no cabeçalho do jornal, assim como indica qual será o direcionamento do mesmo. Ao identificar o "espaço da experiência” apontado por uma leitura abrangente da condição do país, estabelece um "horizonte de expectativa” em que se coloca a favor das reivindicações da "nossa gente explorada”. Ao mesmo tempo se preocupa com a questão relativa à "harmonia planetária" oferecida pelo avanço tecnológico. Nesse sentido, são explícitas as preocupações com o "país e o mundo", não se resumindo apenas a questões envolvendo a cidade de São Paulo. Em relação ao primeiro, continua:

Aqui, capitais estrangeiros deformaram estranhamente a nossa economia. De um país que possui a maior reserva de ferro e o mais alto potencial hidráulico, fizeram um país de sobremesas. Café, açúcar, fumo, bananas. Que nos sobrem ao menos as bananas! Os capitais estrangeiros compraram as nossas quedas d'água e criaram um sórdido e meigo urbanismo colonial que passou a ser o que eles queriam - um dos melhores mercados para os seus produtos e chocalhos. ${ }^{20}$

Nesse primeiro momento, a representação de povo aparece de forma mais ampla, abrangendo todos os brasileiros explorados, em um misto de lavradores, consumidores de produtos estrangeiros, militantes de esquerda e de direita, cavadores, enfim, homens e mulheres à mercê dos interesses capitalistas, principalmente aqueles ligados ao capital externo. Com efeito, essa será a tonalidade das representações presentes no impresso, mas com crescente deslocamento para os estratos mais baixos da hierarquia social, onde, ao que tudo indica, estaria alocado o público-alvo-imaginado para quem o impresso, em um primeiro momento, estaria destinado.

Em artigo intitulado "O nosso programa”, também publicado no primeiro número do impresso, Hélio Negro ${ }^{21}$ faz eco aos posicionamentos de Oswald de Andrade. Segundo o

${ }^{19}$ CAMPOS. O homem do povo: março/abril de 1931, p. 1.

${ }^{20}$ CAMPOS. O homem do povo: março/abril de 1931, p. 1.

${ }^{21}$ Segundo Maria Luiza Tucci Carneiro “Antônio Candeias Duarte [responsável pela Editorial Marenglen], proprietário da tipografia, envolveu-se diretamente com intelectuais da resistência 
artigo, "as velhas formas de produção e consumo estão ameaçadas em todo mundo, assim como as velhas formas de autoridade (...). A produção de escravos, servos e proletários precisa completar a sua evolução até a produção dos associados.”22

O termo empregado “nosso” nos dá uma dimensão de complementaridade ao editorial, assim como a ideia de unidade. Duas características nos chamam a atenção: a persistência do tom universalista e o caráter etapista, ambas as características marcantes da cultura comunista, colocados em termos teleológicos, meios pelos quais os explorados poderiam alcançar a condição de associados - termo que poderia ser facilmente substituído por “classe”. Com efeito, ao deslocar para o universo da política brasileira, afirma que

nós não queremos depender dos favores dos ricos nem dos governos, e por isso a nossa modesta publicação desaparecerá amanhã como aparece hoje, se por ventura vier [a] faltar apoio moral e material das classes pobres, únicas que devem merecer a nossa defesa. E nós não consideramos somente classes pobres os trabalhadores rurais e urbanos, mas também os indivíduos que pertencem à miséria da gravata. $\mathrm{O}$ nosso combate principal será em prol do Jeca Tatu - o filho mais útil da "Mãe Pátria" e também o mais desprezado por essa senhora, que até parece madrasta de certos filhos. ${ }^{23}$

Aqui, povo está conjugado tanto com indivíduos pertencentes à “miséria da gravata”, quanto com a figura emblemática de Monteiro Lobato, o Jeca Tatu. Este, mesmo apresentado como o "filho mais útil” e o "mais desprezado", talvez a classe objetiva e honestamente merecedora de todos os esforços revolucionários, não se configurava como o único colocado em situação de explorado. Para que o programa de reestruturação social pudesse ser levado a cabo seria necessário o esclarecimento de toda a sociedade brasileira.

A figura do Jeca Tatu retorna às páginas do jornal de 31 de março de 1931. Publicado no terceiro número do impresso e em continuidade ao citado acima, Hélio Negro retoma sua linha de argumentação, deslocando sua reflexão para a questão agrícola e para o Jeca.

interessados em multiplicar os conhecimentos sobre a URSS e o ideário socialista (...). Em nota, ao comentar as relações de Candeias com empreendimentos políticos, afirma que "além de publicações deste gênero, a Editorial Merenglen foi acusada de imprimir jornais 'subversivos' como O Homem do Povo, o que lhe valeu guarda diária pela polícia. O próprio Candeias - apesar de afirmar às autoridades policiais que estava afastado das lutas sociais - chegou a escrever para este periódico com o pseudônimo de 'Hélio Negro', até o momento em que se afastou por discordar de Oswald de Andrade.” CARNEIRO. Editando a desordem, p. 57.

${ }^{22}$ CAMPOS. O homem do povo: março/abril de 1931, p. 2.

${ }^{23}$ CAMPOS. O homem do povo: março/abril de 1931, p. 2. 
E a nossa lavoura e o nosso Jeca? Quantas coisas grandiosas poderia fazer o socialismo em seu aproveito. Grandes cooperativas agrícolas, com os seus técnicos, os seus campos experimentais, instalações de irrigação, maquinaria completa, as suas indústrias rurais, a sua produção em vasta escala, postos de higiene, cultura física, instrução profissional e regime alimentar para o Jeca! Em pouco tempo, curado, bem vestido, bem alimentado, bem alojado - o bem instruído Jeca ereto, ter-se-ia esquecido que foi o Jeca de cócoras. ${ }^{24}$

Essa passagem, ao explorar a figura do Jeca como indivíduo típico do trabalho com a lavoura e, por isso, sempre de “cócoras”, nos chama a atenção para a forma como o termo "socialismo" foi colocado em questão. Primeiro, por não haver nenhuma distinção entre as diferenças conceituais com outras perspectivas políticas, como, por exemplo, o comunismo já que em passagem anterior esse conceito havia sido tema da polêmica levantada contra figuras como Plínio Salgado. Com efeito, tudo indica que eles foram usados como sinônimos. Segundo, o Jeca aparece como incapacitado de agir por conta própria, incapaz de tomar consciência de si e de promover uma mudança em relação à sua condição de explorado.

O socialismo aparece como um farol, algo externo à sua condição, que teria o poder de criar condições para que sua vida mudasse para melhor - do Jeca de cócoras para o Jeca ereto. Sente-se o seu apagamento no que tange à esfera da ação. O socialismo (assim como o enunciador do discurso) foi colocado em terceira pessoa, desdobrando-se no silenciamento do Jeca. $^{25}$ Aqui, o homem do povo/Jeca, pensado nesses termos, parece assumir um lugar negativo na configuração do processo revolucionário, tendo o socialismo que assumir o papel da "Mãe pátria (...) que até parece madrasta de certos filhos”, para recuperarmos a citação mais acima.

Em artigo intitulado "Comentários de um homem do povo”, presente no segundo número do impresso, Oswald de Andrade polemiza com Plínio Barreto ${ }^{26}$ no que diz respeito

\footnotetext{
${ }^{24}$ CAMPOS. O homem do povo: março/abril de 1931, p. 2.
}

${ }^{25}$ Pierre Bourdieu, ao trabalhar com a ideia de classe como representação e como vontade, chama a atenção para o fato de que "o porta-voz é aquele que, ao falar de um grupo, ao falar de um lugar de um grupo, põe, sub-repticiamente, a existência do grupo em questão, institui este grupo, pela operação de magia que é inerente a todo o ato de nomeação”. BOURDIEU. O poder simbólico, p. 158.

${ }^{26}$ Plínio Barreto formou-se na Faculdade de Direito de São Paulo, dedicou-se ao jornalismo, trabalhou em diversos periódicos e foi um dos diretores d'O Estado de S. Paulo. Foi chefe do governo provisório do estado de São Paulo durante 21 dias após a Revolução de 1930. Após o Estado Novo foi eleito deputado federal pela União Democrática Nacional e candidato a governador do estado de São Paulo 1946, derrotado por Ademar Pereira de Barros. Junto com outros intelectuais, como, por exemplo, Monteiro Lobato, atuou na defesa da “ordem”, contra a crise revolucionária de 1924, que, segundo Edgar Carone, "levou esse processo burguês-oligárquico a um impasse, apesar de suas 
ao direito de se pronunciarem a respeito do povo. ${ }^{27}$ Segundo Oswald,

o sr. Plínio Barreto, que pontifica pelas colunas do velho, "venerando" e arquiconservador O Estado de S. Paulo, continua no seu inveterado abuso de falar em nome do povo. Todo mundo sabe que povo quer dizer o povo que trabalha, o povo que sofre, o povo oprimido e explorado.

Em seguida, “não acreditamos que haja alguém suficientemente cretino para nos vir dizer que o sr. Crespi é povo, que o sr. Conde de Lara é povo". ${ }^{28}$

A curiosa utilização do "nós” em seu discurso nos induz a pensar em uma dupla estratégia: a primeira seria a reivindicação de Oswald como "homem do povo", uma vez manifestado o interesse em ser ouvido ou, no mínimo, ter voz. Nesse sentido, delega a si mesmo a função de falar como e pelo povo, apresentando-se como porta-voz na defesa dos oprimidos; a segunda seria o esforço investido em uma espécie de "eficácia simbólica”, ${ }^{29}$ que também poderia ser entendida como resultado de “uma magia social”, ao expressar supostos posicionamentos compartilhados por todos aqueles responsáveis pelo impresso, dando uma ideia de conjunto coeso e uno para as reivindicações, ao tentar criar e divulgar um sentimento compartilhado por um grupo a favor da adesão de mais indivíduos.

Na sequência, acusa Barreto e o jornal O Estado de S. Paulo de criminoso e demagógico:

Nessas condições, o sr. Plínio Barreto, o servidor convicto e incondicional de todos os exploradores do povo, deve cessar o abuso, altamente criminoso, de falar em nome do povo, com o qual não tem absolutamente nada de comum.

contínuas campanhas patrióticas”. Ainda para Carone, em 1925, há primeira tentativa de "refrear a 'franca revolta' do povo brasileiro: 'um vício mortal mantém cada vez mais vivo o divórcio entre o governo e a elite do país, vício tão grave, que se não corrigido a tempo arrastará o país à completa ruína. Esse vício é o nosso regime eleitoral de censo baixo". CARONE. Partidos e programas, p. 317.

${ }^{27}$ Ainda para Pierre Bourdieu, "o porta-voz dotado de pleno poder de falar e de agir em nome do grupo e, em primeiro lugar, sobre o grupo pela magia da palavra de ordem, é o substituto do grupo que somente por esta procuração existe; personificação de uma pessoa fictícia, de uma ficção social, ele faz sair do estado de indivíduos separados os que ele pretende representar, permitindolhes agir e falar, através dele, como um só homem”. BOURDIEU. O poder simbólico, p. 158.

${ }^{28}$ CAMPOS. O homem do povo: março/abril de 1931, p. 3.

${ }^{29}$ Para Bourdieu "a eficácia simbólica das palavras se exerce apenas na medida em que a pessoa-alvo reconhece quem a exerce como podendo exercê-la de direito, ou então, que dá no mesmo, quando se esquece de si mesma ou se ignora, sujeitando-se a tal eficácia, como se estivesse contribuindo para fundá-la por conta do reconhecimento que lhe concede”. BOURDIEU. A linguagem autorizada: as condições sociais da eficácia do discurso ritual, p. 95. 
O "Estado", a exemplo do que fazem, hoje, por toda parte, os grandes órgãos reacionários, mantidos e pagos por todas as forças que, num país, trituram a carne e os ossos do povo, não se peja e não sente o mais leve embaraço em fazer, de vez em quando, o seu bocado de demagogia. ${ }^{30}$

Ao fazer eco às referências à revolução social como peça central para as mudanças necessárias nas condições de vida desse povo explorado, o artigo é finalizado com um tom prescritivo. Na chave de um discurso inflamado, misto de denúncia e ameaça, explicita que, em relação à

esta demagogia, porém, fique sabendo, o povo que se previna e a repila; esta demagogia é a mais alta expressão de cinismo que já se viu em todos os grandes da terra nos tempos que correm, tempos difíceis e de incertos. Esta demagogia, povo amigo, disfarça este pavor da grande e inevitável derrota, que se aproxima $(\ldots)^{31}$

Na chave da criação de possíveis referenciais para a ação, assim como para o “esclarecimento” do "homem do povo”, o impresso reclama por uma pedagogia popular, que seja "um programa claro, que não seja a estúpida educação de classes, hoje dominante”.32 Citado de um artigo que levou o referido título de "Pedagogia”, inserido na seção intitulada "Panfleto e doutrina", constante em todos os números, O Homem do Povo agora ataca as mazelas do sistema educacional, para o qual a desinformação aparece como um mal responsável pela manutenção de uma massa de analfabetos e, por consequência, uma falsa elite. Nesse sentido, autoproclama o "dever de assinalar quais as diretrizes da sua crítica e do seu comentário, especialmente no que respeita à educação nacional”.

Ao se apresentar como “crítica de opinião, crítica de boa fé - que não exclui absolutamente uma espinha dorsal, uma sistematização, um sentido. Digamos a palavra toda crítica parcial”, expõe suas propostas em relação aos problemas da inadequação dos “formadores e reformadores" brasileiros, que estariam ainda atrelados aos padrões do Império, “padrão do Sr. D. Pedro II, que Deus guarde”, levados por certas doses de “ecletismo cultural”, responsável por uma “vaga ilustração”. Nesse sentido, lança a questão: “Mas educação aqui no Brasil p’ra que serve?” Em conseguinte resposta, afirma:

Porque o que é incontestável é que o curso primário não desanalfabetiza, o

\footnotetext{
${ }^{30}$ CAMPOS. O homem do povo: março/abril de 1931, p. 3.

${ }^{31}$ CAMPOS. O homem do povo: março/abril de 1931, p. 3.

${ }^{32}$ CAMPOS. O homem do povo: março/abril de 1931, p. 3.
} 
secundário não humaniza - e o superior nem faz profissionais, nem faz sábios, nem faz pesquisadores. Que resta então desta educação? Nada. Porque nada, zero vezes zero, é a cultura de toda a gente. Que ignora por completo os problemas, ou os conhece tão mal como um repórter apressado. (...) A única função social efetiva da educação brasileira tem sido a criação de uma falsa elite, em que se misturam coisas asnáticas a respeito de assuntos concretos e brilhos de rubis, esmeraldas e ametistas - por vezes falsas. $^{33}$

Curioso perceber que nessa passagem o povo é representado como completamente desprovido de cultura, capaz de ignorar "por completo os problemas" enfrentados no dia a dia. Corolário suficiente, mesmo percebido de forma sutil, para a afirmação da necessidade da existência do impresso e da premente revolução social, não expressa nesses termos pelo artigo, mas coexistindo internamente no conjunto do jornal. Se esse "homem do povo", agora generalizado às últimas instâncias pelas colocações deste artigo como inculto, sofria indubitavelmente por carência de informações e, como explicitado em citação anterior, disporia de apenas alguns minutos para a leitura, uma revolução que não abrisse mão dos investimentos na educação como potencialmente (re)formadora desse novo homem-povo certamente colheria a mais-valia deste empreendimento.

O artigo é finalizado com a seguinte passagem:

É contra isso que entra em luta “O Homem do Povo”. Por um programa claro de educação popular, que não seja a estúpida educação de classes, hoje dominante. Educação para todos. Igual para todos (e nem por outra coisa deve ser e pode ser a educação pelo Estado). Por uma educação sistematizada, estruturada, orgânica, que faça produtores e não eruditos massudos, engenheiros de giz e quadro negro, e médicos de formulários e bacharéis de comícios e legemania. ${ }^{34}$

Ao mesmo tempo que o impresso se coloca na luta por um programa de educação popular, se presta a ser “opinião esclarecida” em relação à realidade brasileira (e internacional). Entretanto, sempre insistiu no fato de ser um meio de comunicação dirigido pelo "homem do povo" ao mesmo tempo que, como evidenciado nas últimas citações, esse mesmo povo é representado como desprovido de cultura e/ou incapaz de se mover para uma ação transformadora. ${ }^{35}$

${ }^{33}$ CAMPOS. O homem do povo: março/abril de 1931, p. 3.

${ }^{34}$ CAMPOS. O homem do povo: março/abril de 1931, p. 3.

35 Segundo Nonê [Oswald de Andrade Filho], "Oswald demonstrava uma vontade férrea de ser compreendido. Espremido por duas frentes, uma - a burguesia - condenava-o, espezinhava-o, outra 
Outro tema privilegiado pelo impresso foi o Exército. Assinando com o pseudônimo de Spartacus, o autor tece uma argumentação em que "povo” e "exército” aparecem como uma entidade, que, movidos pelo mesmo destino desde a época da abolição da escravatura e do advento da República, compartilharia dos mesmos anseios por mudanças. Segundo o texto intitulado "Palavras ao Exército":

A saudação do "O Homem do Povo" ao Exército tem a sua razão de ser, a
sua lógica, a sua verdade. Não distinguimos o Exército do povo, pois é no
povo, na massa anônima e sofredora dos que trabalham, e não nos interesses
criadores que acidentalmente o conduzem, que o Exército tem as raízes
profundas da sua força. Força que se traduz pela alta expressão moral de
uma vontade esclarecida e de uma consciência lúcida: a vontade do povo, a
consciência do povo. Trabalhadores e soldados não se diferenciam no
processo social. Ambos caminham para o mesmo destino. Inútil, portanto, é
separá-los. ${ }^{36}$

A representação positiva de povo colocada em movimento, nesse momento, entra em contradição com aquela referida mais acima. Se no artigo "Pedagogia” percebemos a falta de cultura "de toda a gente" e em "O nosso programa” a ausência da vontade-desejo ou manifestação ativa dessa "massa sofredora e anônima”, ali representado na figura do Jeca, talvez demonstrando a carência de orientação moral e ética, nessa passagem esse quadro foi pintado com outras cores. "Povo”, aqui, significa “vontade esclarecida” e "consciência lúcida”, virtudes centrais e indispensáveis na produção da força organizacional militar. Por isso mesmo não faria sentido, nessa argumentação, separar os dois elementos. Povo e Exército estariam trilhando juntos, compartilhando anseios e desejos, vontades e esperanças. Enfim, a massa de soldados também seria povo. A equação feita parece indicar para a impossibilidade de ascensão social via Forças Armadas, uma vez que, mesmo na condição de soldado, ele ainda continuaria na condição de "massa explorada”. Ou que uma das razões (ou a razão principal) da existência do Exército fosse o de atuar como fator de mudança social.

Entretanto, no editorial no sétimo número do impresso, intitulado "As angústias de

- os dirigentes de esquerda - rejeitava-o. Sua fama - individualista, personalista, indisciplinado impressionou mais que o seu desejo de servir. Essa entrega política na realidade representou uma alucinante aventura romântica, um sentimento de vingança, talvez contra a sociedade burguesa que o derrotara socialmente.” BOAVENTURA. O salão e a selva: uma biografia ilustrada de Oswald de Andrade, p. 156-157.

${ }^{36}$ CAMPOS. O homem do povo: março/abril de 1931, p. 3. 
Piratininga” e assinado por “o homem do povo", 37 ao criticar o Manifesto do Partido Democrático de São Paulo ${ }^{38}$ como "precioso e ridículo, como literatura política, nula de visão social, fechado no mais estreito e pífio provincianismo, vertendo apenas o pus que brota dos dois cancros de São Paulo", 39 faz um ataque mordaz contra dois nomes das Forças Armadas: coronel João Alberto e o general Miguel Costa.

Para Edgar Carone,

o Partido Democrático, afinal, aglutina todos esses movimentos anteriores, liderados por ala da dissidência oligárquica do Partido Republicano Paulista. Nascida em 1926, a nova agremiação vai ter ação mais complexa que as outras, porque ela surge num momento em que a sociedade se diversifica cada vez mais, a densidade econômica e social urbana exige novas soluções, e não é mais possível a aglutinação de grupos sociais antagônicos nos mesmos agrupamentos políticos. ${ }^{40}$

Nesse mesmo sentido, encontramos na análise de Sérgio Miceli a problemática dos engajamentos políticos dos intelectuais nas disputas de poder nas instituições oligárquicas, mediante as estratégias conscientes e inescapáveis que os intelectuais elaboravam para se inserirem na classe dirigente. Segundo sua análise, o principal fator de bandeamento dos intelectuais para as fileiras do Partido Democrático era a sua situação de exclusão em face da hegemonia dos quadros intelectuais pertencentes ao PRP, que representava a conjunção dos elementos advindos das famílias e escolas reconhecidamente tradicionais no exercício da liderança política e cultural. ${ }^{41}$

${ }^{37}$ Como foi frequente nos editoriais trazerem a assinatura de Oswald de Andrade, podemos supor que esse também seja de sua autoria.

${ }^{38}$ Em 1930, Oswald teceu sérias críticas ao Partido Democrático. Nesse artigo, sem título no original, afirmou que a "inversão de valores, de idéias e de sentimentos é um dos jogos prediletos com que os camelôs do Partido Democrático se dispõe a embair a curiosidade pública sempre incautamente despertada pela mascatagem de reclame que preside aos seus ajuntamentos”. Curioso perceber que, já nesse momento, as discussões sobre as representações e sobre a fala autorizada sobre a noção de povo já mediavam os debates: "eles [Partido Democrático] exploram principalmente um monopólio de novo gênero, mas sem dúvida mais perigoso do que qualquer concessão de outra espécie: o monopólio do povo! Só eles representam a vontade popular, só eles são os amigos do povo e só eles detêm nas mãos enclavinhadas a liberdade serena que sempre pairou sobre a vida construtiva e ordeira de São Paulo”. ANDRADE. Estética e política, p. 161.

${ }^{39}$ CAMPOS. O homem do povo: março/abril de 1931, p. 1.

${ }^{40}$ CARONE. Partidos e programas, p. 318.

${ }^{41}$ Para Miceli, uma das causas da polêmica que envolveu Oswald com Mário de Andrade teria a ver com a inserção desse nos quadros do PD, uma vez que o próprio Oswald teria representado uma espécie de "dândi” à frente do Partido Republicano Paulista. Segundo Miceli, "em relação a 
Segundo o artigo supracitado,

vencidos pelo fenômeno da agonia capitalista [Partido Democrático], a sua cegueira ideológica atribui intenções comunistas a sinceros consolidadores da Ordem Burguesa, como francamente são o Coronel João Alberto e o General Miguel Costa, com toda a razão mais de uma vez apontados pelo altifalante Luiz Carlos Prestes. ${ }^{42}$

A passagem endossa a representação construída pelo outro artigo, na medida em que, ao fazer referência a um coronel e a um general, os distingue da categoria "soldado", entendida como parte do povo. Nesse sentido, apenas nas patentes mais baixas estiveram alocados os representantes do legítimo "homem do povo".

A figura de Prestes aparece positivada, uma vez que ele é apresentado como um dos nomes ou responsáveis por esse tipo de crítica a determinados segmentos das Forças Armadas. Para Oswald de Andrade, os integrantes do Partido Democrático eram

consolidadores fascistas, a sua boa vontade esbarra na inconcertabilidade da máquina onde inutilmente querem andar. Que entreguem essa lata velha, esse Ford furado sem radiador nem gasolina, ao ganancioso grupo de fazendeiros e professores que ambiciona os últimos lucros do ferro miúdo (...). Que o governo dos tenentes se demita e entregue ao Partido Democrático a máquina podre do Estado Burguês que esganou a economia paulista - para que perante as massas elucidadas, seja essa a última experiência de desastre - é o que deseja e pede o homem do povo. ${ }^{43}$

Para além da representação do povo como “massa elucidada”, a passagem sugere o apoio ao movimento tenentista, corroborando com a citação do nome de Prestes como uma referência crítica, uma vez que o mesmo teve sua trajetória marcada pela formação militar.

Oswald de Andrade, personagem que talvez não tenha alcançado um lugar de mito, no que diz respeito aos seus posicionamentos políticos ou pelas representações das quais foi alvo ou motivador, pode ser considerado um intelectual pouco estudado pela história política. Ora

Oswald, que procurava se impor tanto por suas façanhas intelectuais como pelas sua 'superioridade' social, Mário poderia levar a melhor na competição em torno da liderança do movimento modernista pelo empenho com que buscou diversificar os campos de aplicação de sua competência cultural polivalente”. MICELI. Intelectuais e classe dirigente no Brasil, p. 25.

${ }^{42}$ CAMPOS. O homem do povo: março/abril de 1931, p. 1.

${ }^{43}$ CAMPOS. O homem do povo: março/abril de 1931, p. 1. 
reivindicado por projetos estéticos, ${ }^{44}$ ora filosóficos, ${ }^{45}$ ora rechaçado por seus "excessos”, 46 parece ainda não ocupar um lugar nos estudos do pensamento social e dos intelectuais do século 20 brasileiros.

Ao utilizarmos exclusivamente um impresso efêmero dentro da trajetória jornalística oswaldiana, fica inviável fazer considerações mais aprofundadas sobre os desdobramentos dos embates por ele travados ou as possíveis repercussões provocadas tanto pelo surgimento como pelo desaparecimento de $O$ Homem do Povo. Também não foi possível descobrir quem foram os leitores do impresso. De qualquer modo, ao lançarmos mão da noção de representação, foi nossa intenção analisar como a categoria "povo" foi utilizada pelos autores, assim como as polêmicas por eles alimentadas. Com efeito, talvez nos ajude a entender as relações complexas entre o personagem e suas representações, ou melhor, entre suas práticas e representações.

\section{ABSTRACT}

This article analyses, based on the concept of representation, the newspaper $O$ Homem do Povo, created and published by Oswald de Andrade, in 1931. It is intended to understand which was the uses of the idea of people, as well as Andrade's self-representation as an intellectual engaged in political matters.

\section{KEYWORDS}

Oswald de Andrade, history of intellectuals, political representations

\section{REFERÊNCIAS}

ANDRADE, Oswald de. Prefácio. In: Serafim Ponte Grande. 3. ed. São Paulo: Círculo do Livro, 1988. p. 131-133.

ANDRADE, Oswald de. O rei da vela. São Paulo: Abril Cultural, 1976.

${ }^{44}$ CAMPOS. Uma poética da radicalidade.

${ }^{45}$ NUNES. Antropofagia ao alcance de todos.

${ }^{46}$ Boaventura nos informa, em nota introdutória, que "muita coisa não foi considerada propositalmente, sobretudo alguns estudos de cunho político-partidário, concebidos durante a fase de militância, por serem enfadonhos e completamente desinteressantes". BOAVENTURA. Do órfico e mais cogitações, p. 8. 
ANDRADE, Oswald de. Estética e política. São Paulo: Globo, 1991.

BERSTEIN, Serge. A cultura política. In: RIOUX, Jean-Pierre; SIRINELLI, Jean-François (Org.). Para uma história cultural. Trad. Ana Moura. Lisboa: Estampa, 1998. p. 349-363.

BOAVENTURA, Maria Eugenia. O salão e a selva: uma biografia ilustrada de Oswald de Andrade. São Paulo: Unicamp, 1995.

BOMENY, Helena. Infidelidades eletivas: intelectuais e o poder. In: Constelação Capanema: intelectuais e políticas. Rio de Janeiro: Ed. Fundação Getúlio Vargas, 2001. p. 1135.

BOURDIEU, Pierre. O poder simbólico. 2. ed. Trad. Fernando Tomaz. Rio de Janeiro: Bertrand Brasil, 1998.

BOURDIEU, Pierre. As regras da arte. Trad. Maria Lúcia Machado. 2. ed. São Paulo: Companhia das Letras, 2005.

BOURDIEU, Pierre. A classe como representação e vontade. In: ed. Trad. Fernando Tomaz. Rio de Janeiro: Bertrand Brasil, 1998. p. 157-161. O poder simbólico. 2.

BOURDIEU, Pierre. A linguagem autorizada: as condições sociais da eficácia do discurso ritual. In:__ Economia das trocas lingüísticas: o que falar quer dizer. Trad. Sérgio Miceli. São Paulo: Edusp, 1996. p. 85-96.

CAMPOS, Augusto de. O homem do povo: março/abril 1931. Edição Facsimilar. São Paulo: Imprensa Oficial do Estado, Arquivo do Estado, 1984.

CAMPOS, Haroldo de. Uma poética da radicalidade. In: ANDRADE, Oswald de. Pau-Brasil. Obras completas. 4. ed. São Paulo: Globo, 1991. p. 7-53.

CARNEIRO, Maria Luiza Tucci. Editando a desordem. In: Livros proibidos, idéias malditas. São Paulo: FAPESP, 2002. p. 55-69.

CARONE, Edgar. Partidos e programas. In: . A República Velha: I instituições e classes sociais (1889-1930). São Paulo: Difel, [s.d]. p. 313-345.

CHALMERS, Vera M. 3 linhas e 4 verdades: o jornalismo de Oswald de Andrade. São Paulo: Livraria Duas Cidades, 1976.

DUTRA, Eliana Regina de Freitas; CAPELATO, Maria Helena Rolim. Representação política: de um conceito na historiografia brasileira. In: CARDOSO, Ciro F.; MALERBA, J. Representações: contribuição a um debate transdisciplinar. Campinas: Papirus, 2000. p. 227267.

DUTRA, Eliana Regina de Freitas. História e culturas políticas: definições, usos, genealogias. Varia Historia, Belo Horizonte, UFMG, n. 28, p. 13-28, 2001.

GINZBURG, Carlo. Representação: a palavra, a idéia, a coisa. In: Olhos de madeira: nove reflexões sobre a distância. Trad. Eduardo Brandão. São Paulo: Companhia das Letras, 2001. p. 85-103.

KOSELLECK, Reinhart. Futuro passado: contribuição para a semântica dos tempos históricos. Trad. Wilma Patrícia; Carlos Almeida Pereira. Rio de Janeiro: Contraponto; Editora PUC-Rio, 2006.

MAGALDI, Sábato. O país desmascarado. In: ANDRADE, Oswald de. O rei da vela. 8. ed. 
São Paulo: Globo, 1990. p. 7-16.

MARTINS, Rubens de Oliveira. Um ciclone da paulicéia: Oswald de Andrade e os limites da vida intelectual em São Paulo (dissertação). São Paulo: USP, [s. d.].

MATOS, Olgária Chain Féres. Construção e desaparecimento do herói: uma questão de identidade nacional. Tempo Social, São Paulo, USP, p. 83-90, 1995.

MICELI, Sérgio. Intelectuais e classe dirigente no Brasil. Rio de Janeiro: Difel, 1979.

MOTTA, Rodrigo Patto Sá. Batalhas em torno do mito: Luiz Carlos Prestes. Revista Estudos Históricos, Rio de Janeiro, n. 34, p. 91-115, jul.-dez. 2004.

MOTTA, Rodrigo Patto Sá. O conceito de cultura política. In: ANAIS DO X ENCONTRO REGIONAL DA ANPUH-MG, Mariana, 1996.

NUNES, Benedito. Antropofagia ao alcance de todos. In: ANDRADE, Oswald de. A utopia antropofágica. Obras completas. São Paulo: Globo, 1990. p. 5-39.

RIOUX, Jean-Pierre; SIRINELLI, Jean-François (Org.). Para uma história cultural. Trad. Ana Moura. Lisboa: Estampa, 1998.

RÉMOND, René. Do político. In: Por uma história política. Trad. Dora Rocha. 2. ed. Rio de Janeiro: Editora FGV, 2003. p. 441-450.

SAID, Edward W. Profissionais e amadores. In: Representações do intelectual. Trad. Milton Hatoum. São Paulo: Companhia das Letras, 2005. p. 71-87.

SARTRE, Jean-Paul. O que é o intelectual. In:__. Em defesa dos intelectuais. Trad. Sérgio Goes de Paula. Paulo: Ática, 1994. p. 13-31. 